\title{
Non-endothelial endothelin counteracts hypoxic vasodilation in porcine large coronary arteries
}

\author{
Elise R Hedegaard ${ }^{1 *}$, Edgaras Stankevicius ${ }^{2}$, Ulf Simonsen ${ }^{1}$ and Ole Fröbert ${ }^{1,3}$
}

\begin{abstract}
Background: The systemic vascular response to hypoxia is vasodilation. However, reports suggest that the potent vasoconstrictor endothelin-1 (ET-1) is released from the vasculature during hypoxia. ET-1 is reported to augment superoxide anion generation and may counteract nitric oxide (NO) vasodilation. Moreover, ET-1 was proposed to contribute to increased vascular resistance in heart failure by increasing the production of asymmetric dimethylarginine (ADMA). We investigated the role of ET-1, the NO pathway, the potassium channels and radical oxygen species in hypoxia-induced vasodilation of large coronary arteries.

Results: In prostaglandin $\mathrm{F}_{2 \alpha}\left(\mathrm{PGF}_{2 \alpha}, 10 \mu \mathrm{M}\right)$-contracted segments with endothelium, gradual lowering of oxygen tension from 95 to $1 \% \mathrm{O}_{2}$ resulted in vasodilation. The vasodilation to $\mathrm{O}_{2}$ lowering was rightward shifted in segments without endothelium at all $\mathrm{O}_{2}$ concentrations except at $1 \% \mathrm{O}_{2}$. The endothelin receptor antagonist SB217242 $(10 \mu \mathrm{M})$ markedly increased hypoxic dilation despite the free tissue ET-1 concentration in the arterial wall was unchanged in $1 \% \mathrm{O}_{2}$ versus $95 \% \mathrm{O}_{2}$. Exogenous ET-1 reversed hypoxic dilation in segments with and without endothelium, and the hypoxic arteries showed an increased sensitivity towards ET-1 compared to the normoxic controls. Without affecting basal NO, hypoxia increased $\mathrm{NO}$ concentration in $\mathrm{PGF}_{2 \alpha}$-contracted arteries, and an $\mathrm{NO}$ synthase inhibitor, L-NOARG,(300 $\mu \mathrm{M}, \mathrm{N}^{G}$-nitro-L-Arginine) reduced hypoxic vasodilation. NO-induced vasodilation was reduced in endothelin-contracted preparations. Arterial wall ADMA concentrations were unchanged by hypoxia. Blocking of potassium channels with TEA (tetraethylammounium chloride)(10 $\mu \mathrm{M})$ inhibited vasodilation to $\mathrm{O}_{2}$ lowering as well as to NO. The superoxide scavenger tiron $(10 \mu \mathrm{M})$ and the putative NADPH oxidase inhibitor apocynin $(10 \mu \mathrm{M})$ leftward shifted concentration-response curves for $\mathrm{O}_{2}$ lowering without changing vasodilation to $1 \% \mathrm{O}_{2}$. PEG (polyethylene glycol) catalase $\left(300 \mathrm{u} / \mathrm{ml}\right.$ ) inhibited $\mathrm{H}_{2} \mathrm{O}_{2}$ vasodilation, but failed to affect vasodilation to $\mathrm{O}_{2}$ lowering. Neither did PEG-SOD (polyethylene glycol superoxide dismutase) $\left(70 \mathrm{u} / \mathrm{ml}\right.$ ) affect vasodilation to $\mathrm{O}_{2}$ lowering. The mitochondrial inhibitors rotenone $(1 \mu \mathrm{M})$ and antimycin $\mathrm{A}(1 \mu \mathrm{M})$ both inhibited hypoxic vasodilatation.
\end{abstract}

Conclusion: The present results in porcine coronary arteries suggest NO contributes to hypoxic vasodilation, probably through $\mathrm{K}$ channel opening, which is reversed by addition of ET-1 and enhanced by endothelin receptor antagonism. These latter findings suggest that endothelin receptor activation counteracts hypoxic vasodilation.

\section{Background}

The systemic vascular response to hypoxia is thought to be vasodilation $[1,2]$, although lowering oxygen $\left(\mathrm{O}_{2}\right)$ from $95 \%$ to $1-5 \% \mathrm{O}_{2}$ either induced or enhanced constriction in canine [3,4] and sheep [1,5] large coronary arteries, while moderate hypoxia $(12-40 \%) \mathrm{O}_{2}$ was reported to induce transient contractions in human and

\footnotetext{
* Correspondence: erh@farm.au.dk

'Department of Pharmacology, Aarhus University, Wilhem Meyers Allé 4,

Bldg. 1240, 8000 Aarhus C, Denmark

Full list of author information is available at the end of the article
}

porcine coronary arteries, and only vasodilation in response to anoxia $[1,6]$. Reports also indicate that the potent vasoconstrictor endothelin-1 (ET-1) is released from the vasculature during hypoxia [7,8]. ET-1 is critical in the development of cardiovascular diseases such as pulmonary hypertension, atherosclerosis, hypertension, and heart failure where hypoxia is a central feature [9]. ET-1 was reported to augment superoxide anion generation in human endothelial cells, suggesting a mechanism for enhanced susceptibility to atherosclerosis [10], and it was found that asymmetric dimethylarginine

\section{Biomed Central}


(ADMA) and ET-1 levels correlate with the extent of intimal hyperplasia [11]. Moreover, ET-1 was proposed to contribute to increased vascular resistance in heart failure by increasing the production of ADMA [12]. We found that the plasma concentration of ADMA rises following coronary angioplasty in patients with myocardial infarction and in patients with stable angina pectoris which are events associated with localised and general tissue hypoxia [13]. ET-1 may also counteract nitric oxide (NO) vasodilation by increasing the levels of free radical oxygen species $[10,14,15]$. Thus, superoxide anions may react with $\mathrm{NO}$ to generate peroxynitrite $\left(\mathrm{ONOO}^{-}\right)$, and hence lower the NO concentration, or be converted by superoxide dismutase to hydrogen peroxide [16]. Thus, many mechanisms have been suggested to contribute to the hypoxic response in coronary arteries. Therefore, we have revisited the role of endothelial factors in the arterial response to hypoxia.

In the present study, we hypothesized that endothelium-derived factors modulate hypoxic vasodilation in large porcine coronary arteries. To address this hypothesis the following measurements were performed: (1) the role of endothelin was investigated by functional studies in isolated coronary arteries and measurement of ET-1 in the vascular wall, (2) the role of NO was evaluated by use of NO synthase and guanylyl cyclase inhibitors, and simultaneous measurements of the NO concentration and vascular contractility were performed, (3) ADMA levels in the vascular interstitial fluid were measured, (4) the involvement of the endothelial cell layer in acute hypoxic vasodilation was investigated by oxygen lowering performed in coronary arteries with and without endothelium, (5) involvement of potassium channels was investigated by adding a potassium channel blocker, tetraethylammonium (TEA), (6) a role for radical oxygen species was investigated by addressing the effect of scavengers of superoxide and $\mathrm{H}_{2} \mathrm{O}_{2}$, as well as inhibitors of the mitochondrial electron transport.

The precise oxygen tension in a large coronary artery wall is relatively unknown. In large arterial preparations e.g. rabbit and porcine aorta exposed to $21 \% \mathrm{O}_{2}, \mathrm{O}_{2}$ tension was found to fall and reach very low levels in media of the vascular wall [17]. Therefore, in the present study we have chosen to gradually lower organ bath oxygen tension from $95 \% \mathrm{O}_{2}(722 \mathrm{~mm} \mathrm{Hg})$ to $1 \%$ $\mathrm{O}_{2}(7.6 \mathrm{~mm} \mathrm{Hg})$.

\section{Methods}

\section{Ethics Statement}

Hearts from Landrace-Yorkshire hogs were obtained at a local slaughterhouse. All experiments conformed to the European Convention for the Protection of Vertebrate Animals used for Experimental and other Scientific Purposes [18].

\section{Tissue}

Immediately after sacrifice the aorta was cannulated and the coronary circulation perfused with physiological saline solution (PSS) containing glucose $5.5 \mathrm{mM}$, bubbled with $5 \% \mathrm{CO}_{2}$ in $\mathrm{O}_{2}$ and buffered with HEPES (for composition see [19]). The hearts were bathed in PSS at $5^{\circ} \mathrm{C}$ for approximately 2 hours until the start of the experiment. The left anterior descending coronary artery (LAD) was carefully dissected and the proximal $3-4 \mathrm{~cm}$ of the artery was left intact (pressure myograph) or cut into a maximum of 4 segments each being $2 \mathrm{~mm}$ long, and each of the segments was used in different treatments. Therefore, each experiment equals one pig (wire myograph). In some experiments the endothelium was removed by gentle rubbing of the lumen with a thin wooden stick.

\section{Functional myograph studies}

Coronary artery segments were mounted for isometric tension recordings in a 4-chamber wire myograph (DMT, Tissue Bath System 700MO, Aarhus, Denmark) containing $5^{\circ} \mathrm{C}$ PSS bubbled with $95 \% \mathrm{O}_{2}, 5 \% \mathrm{CO}_{2}$. Temperature was raised to $37^{\circ} \mathrm{C}$ and the arteries were normalized according to a standard procedure [20]. Arteries were allowed to equilibrate for approximately 30 minutes. Before running the experiment, preparation viability was examined by exposing arteries to potassium-rich PSS ( $\left.\mathrm{K}^{+} \mathrm{PSS}, 123.5 \mathrm{mM}\right)$. The dilatory response to hypoxia was evaluated following a stable contractile response to prostaglandin $\mathrm{F}_{2 \alpha}\left(\mathrm{PGF}_{2 \alpha}\right)$ $10 \mu \mathrm{M}$. After the experiment arteries were contracted with $\mathrm{PGF}_{2 \alpha}(10 \mu \mathrm{M})$ and removal of the endothelial layer was evaluated by lack of response $(<10 \%$ vasodilation) to bradykinin $30 \mathrm{nM}$ (see Figure 1). Appropriate gas composition was obtained by mixing $95 \% \mathrm{O}_{2}$, $5 \%$ $\mathrm{CO}_{2}$ with $95 \% \mathrm{~N}_{2}, 5 \% \mathrm{CO}_{2}$ using a gasmixer (Digamix, $\mathrm{H}$. Wösthoff $\mathrm{GmbH}$, Bochum, Germany). The organ bath was bubbled through glass tubes with pimpstone allowing rapid equilibration of the oxygen tension set by the pump. The gas tension was set to $95 \% \mathrm{O}_{2}(722 \mathrm{~mm}$ $\mathrm{Hg}$ ), $40 \% \mathrm{O}_{2}$ (304 $\mathrm{mm} \mathrm{Hg}$ ), 20\% $\mathrm{O}_{2}(152 \mathrm{~mm} \mathrm{Hg}), 10 \%$ $\mathrm{O}_{2}(76 \mathrm{~mm} \mathrm{Hg}), 5 \% \mathrm{O}_{2}(38 \mathrm{~mm} \mathrm{Hg})$, and $1 \% \mathrm{O}_{2}$ (7,6 mm Hg). Oxygen concentration was measured with an oxygen electrode (Unisense, Aarhus, Denmark), and the measured oxygen concentrations were $92.4 \pm 0.7 \%$, $39.6 \pm 0.4 \%, 20.2 \pm 0.2 \%, 11.0 \pm 0.2 \%, 5.8 \pm 0.2 \%$, and $1.2 \pm 0.3 \%(\mathrm{n}=8)$.

The oxygen curve was performed by maintaining the oxygen level at a fixed concentration until steady state before changing to the next level. We investigated the role of the endothelin receptor antagonist SB217242 $(10 \mu \mathrm{M})$, the competitive NO synthase inhibitor $\mathrm{N}^{\mathrm{G}}$ nitro-L-Arginine (L-NOARG, $300 \mu \mathrm{M}$ ), the potassiumselective ion channel blocker TEA $(10 \mu \mathrm{M})$, the free 


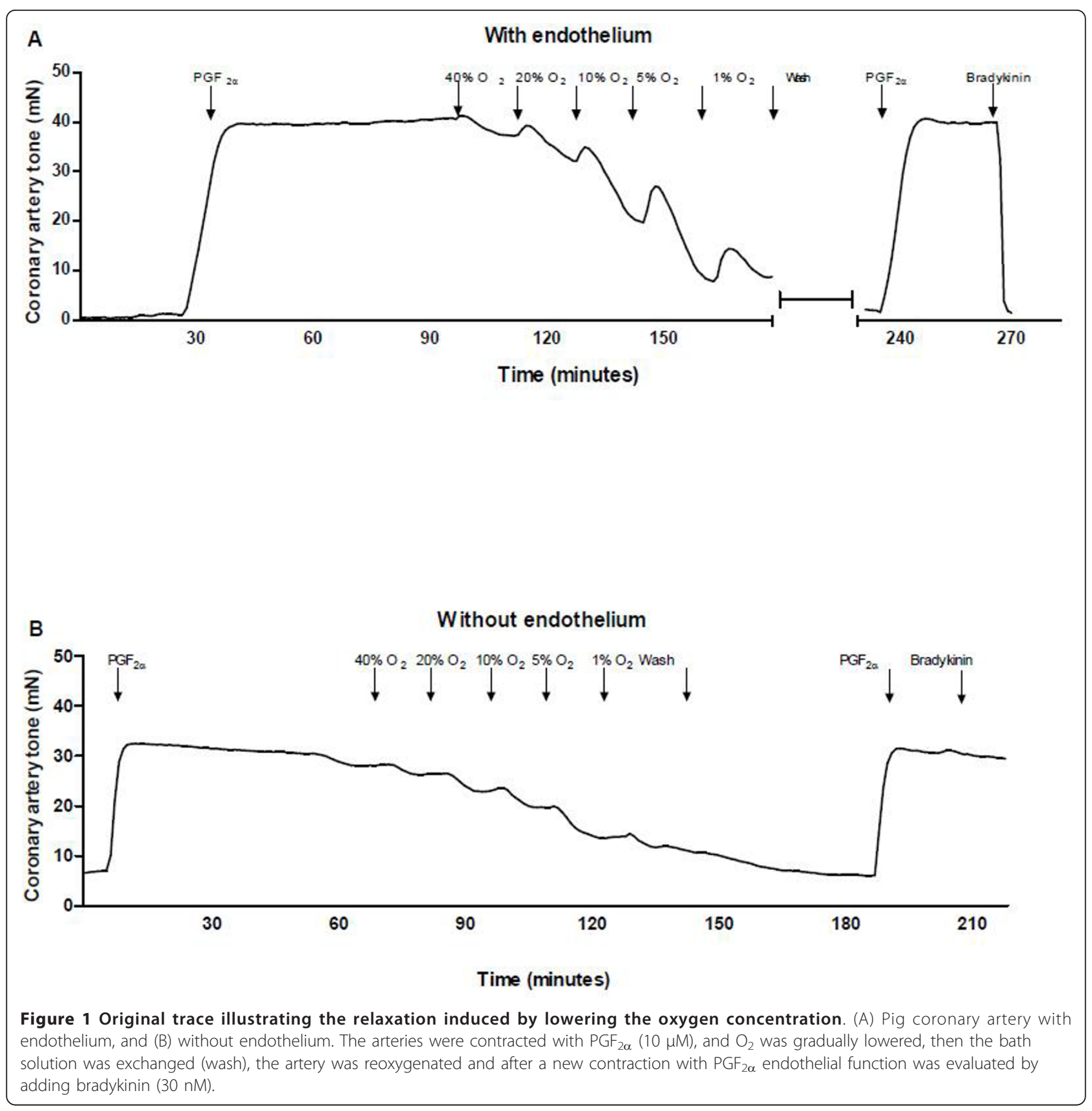

radical scavenger tiron $(10 \mu \mathrm{M})$, the putative NADPH oxidase inhibitor apocynin $(10 \mu \mathrm{M})$, the catalyst for $\mathrm{H}_{2} \mathrm{O}_{2}$ decomposition PEG catalase $(300 \mathrm{u} / \mathrm{ml})$, the catalyst for dismutation of superoxide PEG-SOD $(70 \mathrm{u} / \mathrm{ml})$, and the mitochondrial inhibitors rotenone $(1 \mu \mathrm{M})$, and antimycin $\mathrm{A}(1 \mu \mathrm{M})$. These were incubated 30 minutes prior to $\mathrm{PGF}_{2 \alpha}$ contraction. We performed concentration-response curves for ET- $1\left(10^{-11}-3 \times 10^{-8} \mathrm{M}\right)$, and the influence of oxygen and $\mathrm{NO}$ on the arteries was examined. In another set of experiments, the arteries were normalized and tested for the presence of endothelium before an inhibitor of guanylyl cyclase $1 \mathrm{H}$ $[1,2,4]$ oxadiazolo[4,3-a]quinoxalin-1-one (ODQ) $(3 \mu \mathrm{M})$ was added and left until steady state before arteries were contracted with either $\mathrm{PGF}_{2 \alpha}(1 \mu \mathrm{M})$ or ET-1 in appropriate amounts (1-10 $\mathrm{nM})$ to reach similar levels of contraction. Oxygen or NO concentration-response curves were performed.

Tissue concentrations of ET-1 were determined in arterial segments mounted in wire myographs and contracted with $10 \mu \mathrm{M} \mathrm{PGF}_{2 \alpha}$, and exposed to hypoxia or oxygenation for $60 \mathrm{~min}$. After treatment the arteries 
were frozen in cold acetone and dry ice at $-78^{\circ} \mathrm{C}$. Before homogenization the tissue was allowed to equilibrate at room temperature for 2 hours before the dried tissue was weighed. The samples were homogenized in EIA buffer from the ET-1 ELISA kit using a Precellys 24 homogenizer (Bertin Technologies, Montigny-le-Bretonneux, France). The samples were exposed to 3 cycles at $5000 \mathrm{rpm}$ for 30 seconds each. After homogenization the samples were centrifuged at $10.000 \mathrm{rpm}$ for $10 \mathrm{~min}$ at $4{ }^{\circ} \mathrm{C}$, and the supernatant was collected and kept at $-80^{\circ} \mathrm{C}$. The ET- 1 content in each sample was quantified with an ELISA assay (Immuno-Biological Laboratories Co., Ltd, Japan) according to the manufacturer's instructions. This assay is a solid phase sandwich ELISA using 2 kinds of highly specific antibodies. Tetra Methyl Benzidine (TMB) was used as colouring agent (chromogen); the strength of colouring was proportional to the quantity of ET-1.

\section{Simultaneous measurements of NO concentration and force}

For simultaneous measurement of force and NO concentration, an NO sensitive microelectrode (ISONOP30, World Precision Instruments, Stevenage, UK) was used. The calibration of the electrode was performed at $21 \%$ and $1 \% \mathrm{O}_{2}$ by use of an NO solution and then introduced into the lumen of the artery mounted in a single channel wire myograph as previously described $[19,21]$. To test selectivity of the electrodes, a lack of response to sodium nitrite of up to $10 \mu \mathrm{M}$ was regarded as evidence for an intact coating of the electrode. Noradrenaline is oxidized on carbon fibres if electrode coating is damaged, and electrodes were discarded if noradrenaline $(0.5 \mu \mathrm{M})$, in the absence of vascular tissues, increased electrode current.

Coronary arterial segments $2 \mathrm{~mm}$ in length were suspended in a wire myograph (DMT, Tissue Bath System) for force measurements and the microelectrode was introduced into the lumen. To investigate the role of basally-released NO, simultaneous measurements of force and NO concentration were performed in both the absence and presence of a scavenger of free NO, oxyhaemoglobin $(10 \mu \mathrm{M})$. To evaluate the effect of agonist induced relaxation and NO release, artery rings were contracted with $\mathrm{PGF}_{2 \alpha}, 10 \mu \mathrm{M}$, and bradykinin was added.

\section{Functional testing and interstitial concentration of ADMA}

Two $\mathrm{cm}$ long cylindrical arterial segments were mounted at both ends on a stainless steel cannulae and fastened with sutures in PSS bubbled with $5 \% \mathrm{CO}_{2}$ in $\mathrm{O}_{2}$ in a pressure myograph (110P XL, DMT). The temperature was raised to $37 \mathrm{C}$. Previous to the measurements the segments were stretched to the in situ length using a micrometer device. A transmural pressure of $40 \mathrm{~mm} \mathrm{Hg}$ was applied for a 1-hour stabilizing period as well as during the experiments. We previously found this to be optimal in terms of coronary arterial response to an agonist in a pressure myograph [22]. The external diameter of the arterial segment was automatically determined by video imaging at a frequency of $20 \mathrm{~Hz}$. The internal pressure was controlled by adjustment of two reservoirs containing PSS mounted on a pressure column and connected to the cannulae. Pressure transducers close to the "arterial" end of each cannula measured the internal pressure. Transmural pressure, the outer diameter, and a video image of the arterial segment were continuously sampled and stored on computer (Myodaq software, version 2.03, DMT). Before and after experiments the video dimension analyser was calibrated by use of a $3000 \times$ $3000 \mu \mathrm{m}^{2}$ phantom in the horizontal and vertical directions.

After a stabilising period in the organ bath, artery tone was induced with $\mathrm{PGF}_{2 \alpha}$. When a stable constriction was established, hypoxia was induced by adjusting the gas concentrations from $5 \% \mathrm{CO}_{2}$ in $\mathrm{O}_{2}$ (organ bath $\mathrm{PO}_{2}>650 \mathrm{~mm} \mathrm{Hg}$, ISO2-D, WPI, Fl) to $5 \% \mathrm{CO}_{2}$ in $\mathrm{N}_{2}$ resulting in $1 \% \mathrm{O}_{2}$ in the organbath $\left(\mathrm{PO}_{2} 30 \mathrm{~mm} \mathrm{Hg}\right)$. The influence of $60 \mathrm{~min}$ of hypoxia was studied. Oxygenated conditions were re-established by switching back to PSS equilibrated with $5 \% \mathrm{CO}_{2}$ in $\mathrm{O}_{2}$ and the arterial response during the following $60 \mathrm{~min}$ was recorded (reoxygenation period). Organ bath $\mathrm{pH}$ was constant at 7.4.

In other experiments a microdialysis catheter (CMA/7, CMA, Sweden) was placed in the smooth muscle interstitium of a coronary artery mounted in the pressure myograph as previously described [23]. The microdialysis catheter has a $6 \mathrm{kDa}$ molecular cut-off and an outer diameter of $0.24 \mathrm{~mm}$. Perfusion of the catheter was started immediately after mounting at a rate of $0.3 \mu \mathrm{l} /$ min with isotonic saline. Thirty-minute samples of dialysate $(9 \mu \mathrm{l} / \mathrm{sample})$ were collected. There was a delay of $12 \mathrm{~min}$ between the passage of the perfusate through the microdialysis catheter and collection in vials. This time delay was considered in the calculations and all data are presented in real time. Microdialysis samples were collected 60 min prior to hypoxia, during hypoxia, and during reoxygenation. In a subset of experiments ADMA $10 \mu \mathrm{M}$ was added to the organ bath at baseline.

Concentrations of dialysate ADMA concentrations were determined by high-performance liquid chromatography (HPLC, fluorescence detector) and precolumn derivation with o-pthaldialdehyde according to previous studies $[24,25]$. Standard curves for ADMA were constructed before each analysis. 


\section{Statistics}

Values are presented as mean \pm SEM and number of vessels (one per pig). Because the coronary artery diameter varied between pigs, the steady state diameters induced by $\mathrm{PGF}_{2 \alpha}$ were used as an internal standard (100\%). Two-way analyses of variance and paired t-tests were used to test for differences between groups. Differences were considered statistically significant when $\mathrm{P}<$ 0.05 .

\section{Results}

In $\mathrm{PGF}_{2 \alpha}(10 \mu \mathrm{M})$ contracted coronary arterial segments with endothelium lowering of $\mathrm{O}_{2}$ resulted in a transient increase in tension followed by relaxation which was most pronounced at $1 \% \mathrm{O}_{2}$ (Figure $1 \mathrm{~A}$ ). In segments without endothelium, the concentration-response curve for lowering $\mathrm{O}_{2}$ was rightward shifted (Figure 1B, Figure $2 \mathrm{~A})$, but the relaxation induced by $1 \% \mathrm{O}_{2}$ was similar in segments with $(73.2 \pm 7.2 \%, \mathrm{n}=5)$ and without endothelium $(75.0 \pm 3.1 \%, \mathrm{n}=4)$. In a pressure myograph, $1 \% \mathrm{O}_{2}$ also increased diameter in segments with endothelium $(19.4 \pm 2.7 \%, \mathrm{n}=14)$ to a similar degree as in segments without endothelium $(20.8 \pm 2.6 \%, \mathrm{n}=14)$.

The endothelin receptor antagonist SB217242 significantly increased hypoxic relaxation regardless of the presence or absence of endothelium (Figure 2A). Addition of SB217242 to the organ bath resulted in less than $1 \%$ reduction in tone indicating limited ET- 1 mediated basal vasoconstrictor tone in the coronary arteries. Tissue ET-1 was measured in arteries both with and without endothelium exposed to 1 hour of hypoxia compared to normoxic controls and no statistical differences in ET-1 concentration were found (Figure 2B). ET-1 added to the organ bath in control experiments could also be detected. Concentration response curves were constructed for ET-1, and we found ET-1 reversed vasodilation induced by $1 \% \mathrm{O}_{2}$ in arteries with and without endothelium. The sensitivity towards ET-1 was increased at $1 \% \mathrm{O}_{2}$ compared to $95 \% \mathrm{O}_{2}$ both in arteries with and without endothelium (Figure 2C).

Concentration-responses for exogenously added NO were rightward shifted in coronary arterial segments contracted to the same level with endothelin compared to $\mathrm{PGF}_{2 \alpha}$ (Figure $3 \mathrm{~A}$ ). In $\mathrm{PGF}_{2 \alpha}$ and ET-1 contracted arterial segments, an inhibitor of guanylyl cyclase, ODQ $(3 \mu \mathrm{M})$ inhibited the response to exogenously added NO markedly (Figure 3A), but failed to change the response to $\mathrm{O}_{2}$ lowering (Figure 3B). Coronary arterial relaxation induced by $\mathrm{O}_{2}$ lowering from 95 to $1 \% \mathrm{O}_{2}$ was reduced after inhibition of nitric oxide synthase with L-NOARG $300 \mu \mathrm{M}$ (Figure 3C).

Basal NO release was evaluated by the addition of a scavenger of NO, oxyhaemoglobin $(10 \mu \mathrm{M})$ and basal release of $\mathrm{NO}$ was calculated as a reduction in electrode
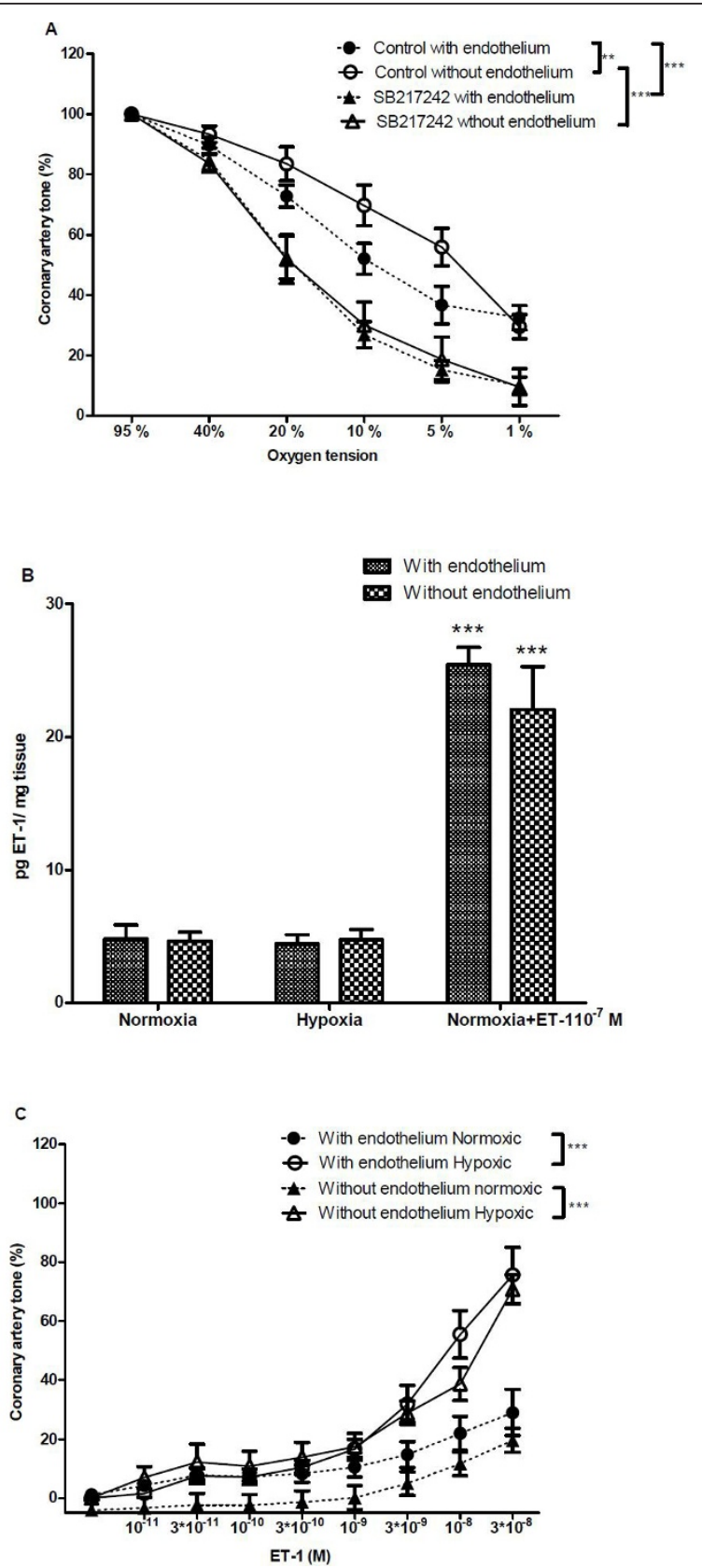

Figure 2 Effect of the endothelin receptor antagonist SB217242 on hypoxic vasodilation. (A) Effect of the endothelin receptor antagonist SB217242 (10 $\mu \mathrm{M})$ on concentration-response curves for oxygen $\left(\mathrm{O}_{2}\right)$ lowering in coronary arterial segments with and without endothelium contracted with PGF $2 \alpha(10 \mu \mathrm{M})$. (B) Tissue ET-1 in arteries exposed to $1 \mathrm{~h}$ of hypoxia $\left(5 \% \mathrm{CO}_{2}, 95 \% \mathrm{~N}_{2}\right)$ compared to normoxic controls. By adding ET-1 $\left(10^{-7} \mathrm{M}\right)$ to the organ bath we were able to measure ET-1 $(P<0.001)$. (C) Concentration-response curves for increasing concentrations of ET-1 in coronary artery segments with and without endothelium and constricted with $\mathrm{PGF}_{2 \alpha}(10 \mu \mathrm{M})$ and subsequently exposed to $1 \% \mathrm{O}_{2}$ or $95 \% \mathrm{O}_{2}$ for $30 \mathrm{~min}$ as well as during the rest of the experiments. Results are means \pm SEM of 4-9 experiments. Differences were evaluated with two-way ANOVA followed by Bonferroni post-test: * $P<0.05$, ${ }^{* *} P<0.01$, ${ }^{* *} P<0.001$ compared to control. 

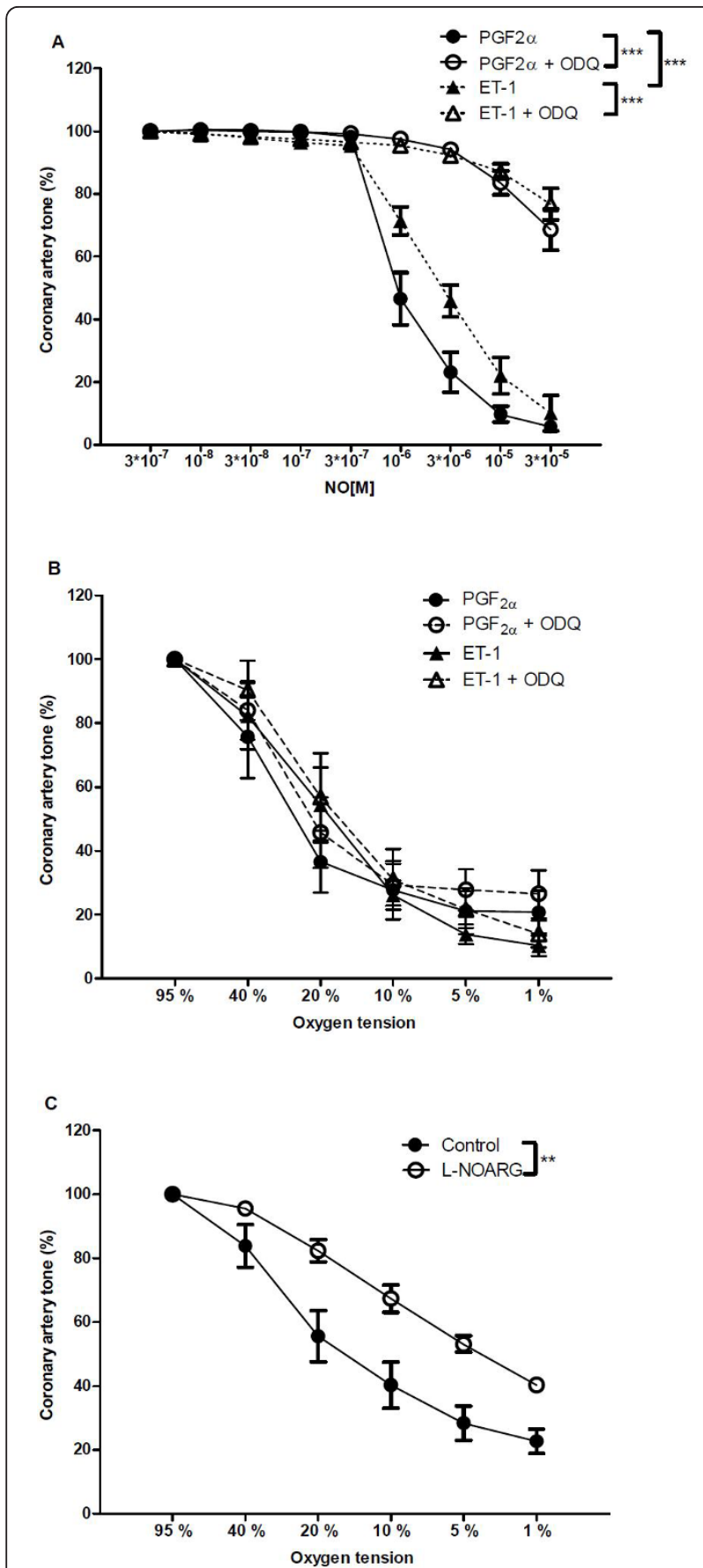

Figure 3 Role of the nitric oxide (NO)-cyclic GMP pathway in hypoxic vasodilation. (A) Concentration-response curves for NO in the absence and the presence of an inhibitor of soluble guanylyl cyclase, ODQ $\left(3 \times 10^{-6} \mathrm{M}\right)$ in arteries contracted with endothelin or $\mathrm{PGF}_{2 \alpha}$. (B) Concentration-response curves for $\mathrm{O}_{2}$ lowering in the absence and the presence of an inhibitor of soluble guanylyl cyclase, ODQ $\left(3 \times 10^{-6} \mathrm{M}\right)$ in arteries contracted with endothelin or $\mathrm{PGF}_{2 \alpha}$ (C) Concentration-response curves for $\mathrm{O}_{2}$ lowering in the absence and the presence of an inhibitor of NO synthase, L-NOARG $\left(3 \times 10^{-4} \mathrm{M}\right)$. Results are means \pm SEM of 6 experiments. Differences were evaluated with two-way ANOVA with Bonferroni post-test: * $P$ $<0.05,{ }^{* *} P<0.01,{ }^{* * *} P<0.001$ compared to control.

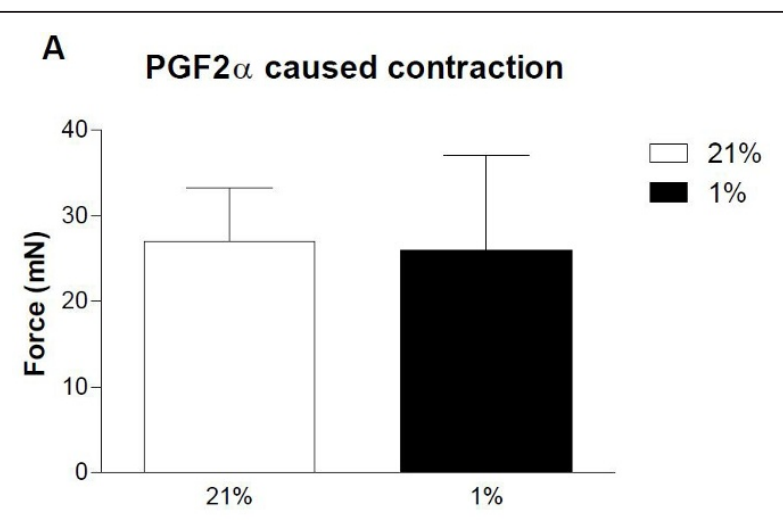

B Effect of PGF2 $\alpha$ on the release
of NO

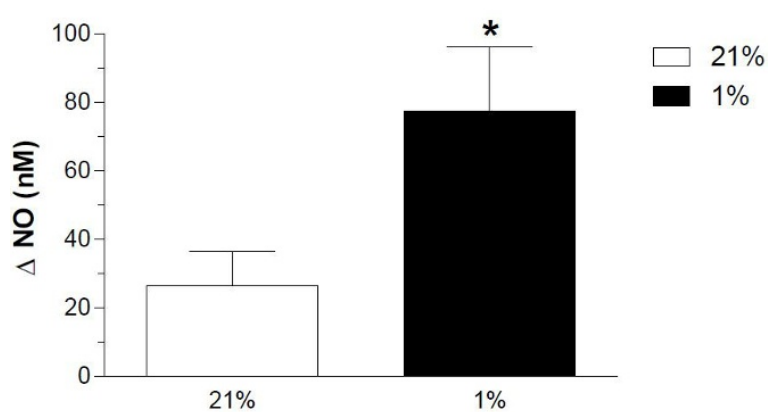

Figure 4 Effect of acute hypoxia on nitric oxide release. Effect of acute hypoxia $\left(1 \% \mathrm{O}_{2}\right)$ on $(\mathrm{A})$ constriction to $\mathrm{PGF}_{2 \alpha}$ and $(\mathrm{B})$ the release of NO. Results are means \pm SEM of 5 experiments.

Differences were evaluated with a paired $t$ test: ${ }^{*} P<0.05$ versus control,

current as previously reported [19]. The procedure was performed during both normoxic and hypoxic conditions. There was no significant difference in basal release of $\mathrm{NO}$ at $21 \% \mathrm{O}_{2}(64.2 \pm 16 \mathrm{nM}, \mathrm{n}=6)$ versus $1 \% \mathrm{O}_{2}(64.3 \pm 14 \mathrm{nM}, \mathrm{n}=5)$. In arteries contracted to the same level by adding additional $\mathrm{PGF}_{2 \alpha}$ (Figure $4 \mathrm{~A}$ ), the $\mathrm{NO}$ concentration was markedly enhanced at $1 \% \mathrm{O}_{2}$ compared to $21 \% \mathrm{O}_{2}$ (Figure $4 \mathrm{~B}$ ). Dialysate concentrations of the NO synthase inhibitor ADMA from arteries investigated in normal HEPES were at the lower detection limit $(<0.06 \mu \mathrm{M})$ and showed no tendency to increase during hypoxia. We found that following the addition of ADMA $10 \mu \mathrm{M}$ to the organ bath, significant amounts of ADMA could be recovered in the dialysate and this was independent of oxygenation $\left(21 \% \mathrm{O}_{2}: 1.9 \pm\right.$ $0.3 \mu \mathrm{M} ; 1 \% \mathrm{O}_{2}: 2.0 \pm 0.3 \mu \mathrm{M}, \mathrm{n}=6$ ).

A non-specific potassium channel blocker, TEA significantly inhibited relaxation induced by $\mathrm{O}_{2}$ lowering (Figure 5A). Concentration-responses for exogenously added NO were significantly inhibited in the presence of TEA 


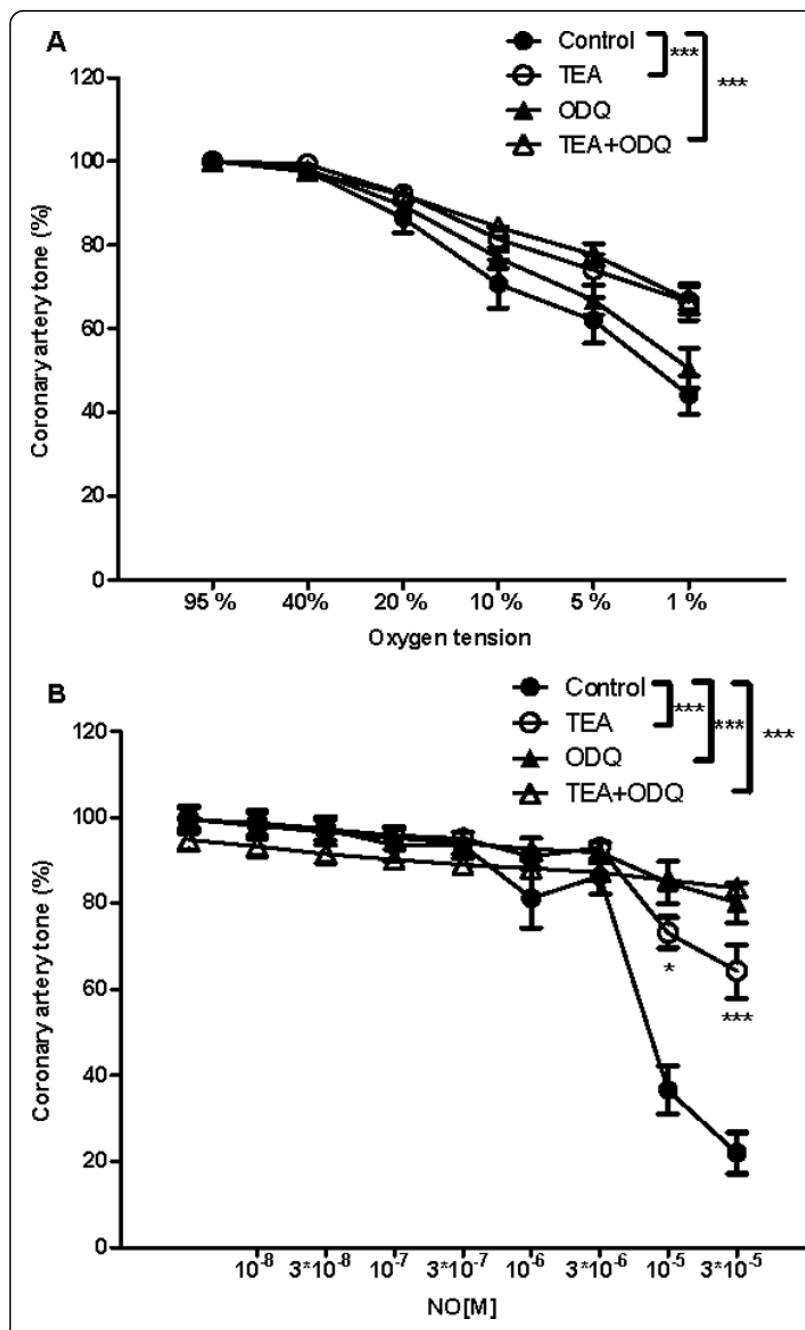

Figure 5 Effect of the potassium channel blocker TEA on hypoxic vasodilation. (A) Concentration-response curves for $\mathrm{O}_{2}$ lowering in the absence and the presence of an inhibitor of soluble guanylyl cyclase, ODQ $\left(3 \times 10^{-6} \mathrm{M}\right)$ and the absence or presence of the potassium channel blocker TEA $(10 \mu \mathrm{M})$. (B) Concentrationresponse curves for $\mathrm{NO}$ in the absence and the presence of an inhibitor of soluble guanylyl cyclase, ODQ $\left(3 \times 10^{-6} \mathrm{M}\right)$ and the absence or presence of the potassium channel blocker TEA $(10 \mu \mathrm{M})$. Results are means \pm SEM of 8 experiments. Differences were evaluated with two-way ANOVA with Bonferroni post-test: ${ }^{*} \mathrm{P}<$ $0.05,{ }^{* *} P<0.01,{ }^{* * *} P<0.001$ compared to control.

(Figure 5B). A subanalysis showed that the presence of ODQ $(3 \mu \mathrm{M})$ together with TEA gave an additional inhibition of NO induced relaxation as compared to TEA alone at $10^{-5}$ and $3 * 10^{-5} \mathrm{M}$ NO.

In arteries with endothelium, the transient contractions disappeared and a leftward shift in concentrationresponse curves for $\mathrm{O}_{2}$ lowering was observed in segments treated with the superoxide scavenger, tiron, while tiron had no effect in segments without endothelium (Figure 6A). In arterial segments with endothelium, an inhibitor of superoxide formation, apocynin leftward
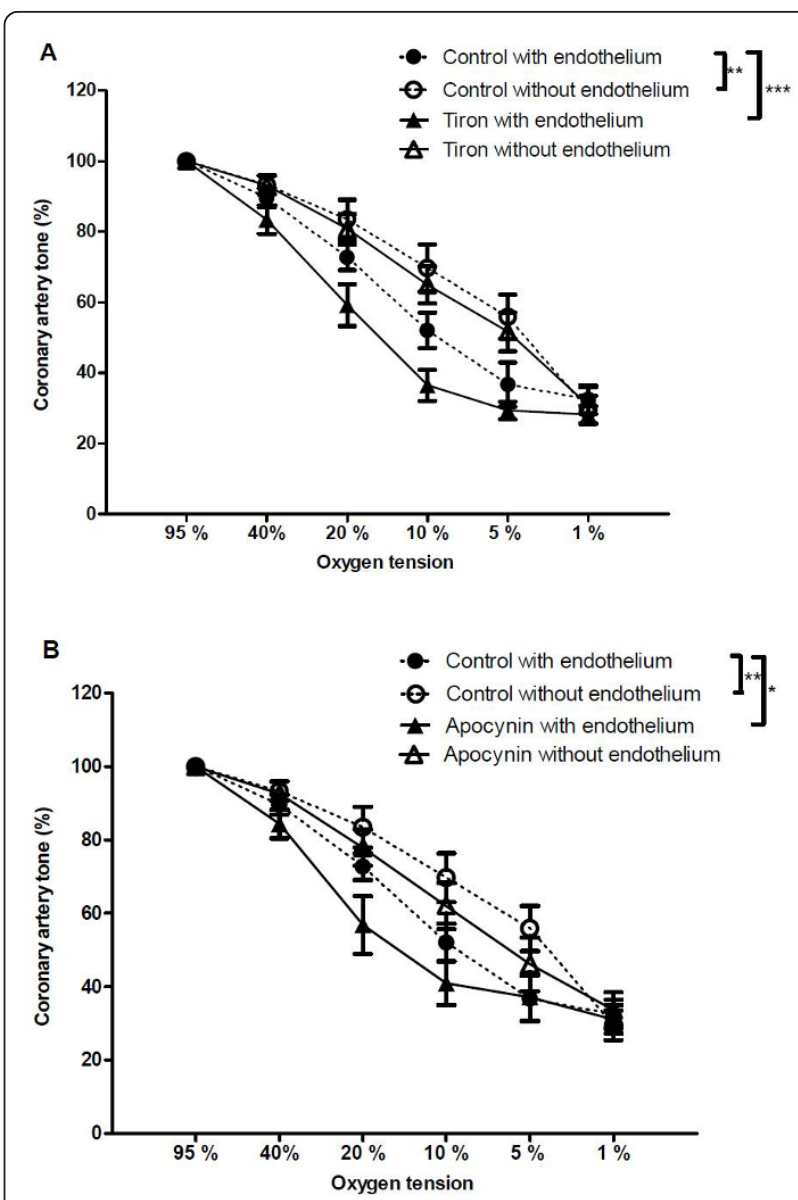

Figure 6 Effect of the free radical scavenger tiron and the putative NADPH oxidase inhibitor apocynin on hypoxic vasodilation. Effect of $(A)$ the free radical scavenger tiron $(10 \mu \mathrm{M})$ and (B) the putative NADPH oxidase inhibitor, apocynin (10 $\mu \mathrm{M})$ on concentration-response curves for oxygen lowering in coronary arterial segments contracted with $\mathrm{PGF}_{2 \alpha}(10 \mu \mathrm{M})$. Results are means \pm SEM of 8-9 experiments. Differences were evaluated with two-way ANOVA with Bonferroni post-test: ${ }^{*} \mathrm{P}<0.05$, ${ }^{* *} \mathrm{P}<0.01$, ${ }^{* * *} \mathrm{P}<$ 0.001 compared to control.

shifted concentration-response curves for $\mathrm{O}_{2}$ lowering, but this was not the case for arteries without endothelium (Figure $6 \mathrm{~B}$ ). The vasodilation to $1 \% \mathrm{O}_{2}$ was unaltered in the presence of either tiron or apocynin. Additional tests of the potential role of $\mathrm{H}_{2} \mathrm{O}_{2}$ showed that the cell permeable enzyme PEG catalase $300 \mathrm{u} / \mathrm{ml}$ failed to change hypoxic relaxation (Figure 7A) while $\mathrm{H}_{2} \mathrm{O}_{2}$-induced relaxation was inhibited (Figure 7B). A test for the potential role of superoxide showed that PEG-SOD $70 \mathrm{u} / \mathrm{ml}$ failed to change the curves for $\mathrm{O}_{2}$ lowering (Figure 7C).

The mitochondrial inhibitors rotenone $(1 \mu \mathrm{M})$ and antimycin A $(1 \mu \mathrm{M})$ both significantly inhibited vasodilatation to $\mathrm{O}_{2}$ lowering (Figure $8 \mathrm{~A}$ ). The combination of the two inhibitors did not have an additional effect compared to either of the inhibitors alone (Figure 8A). The 


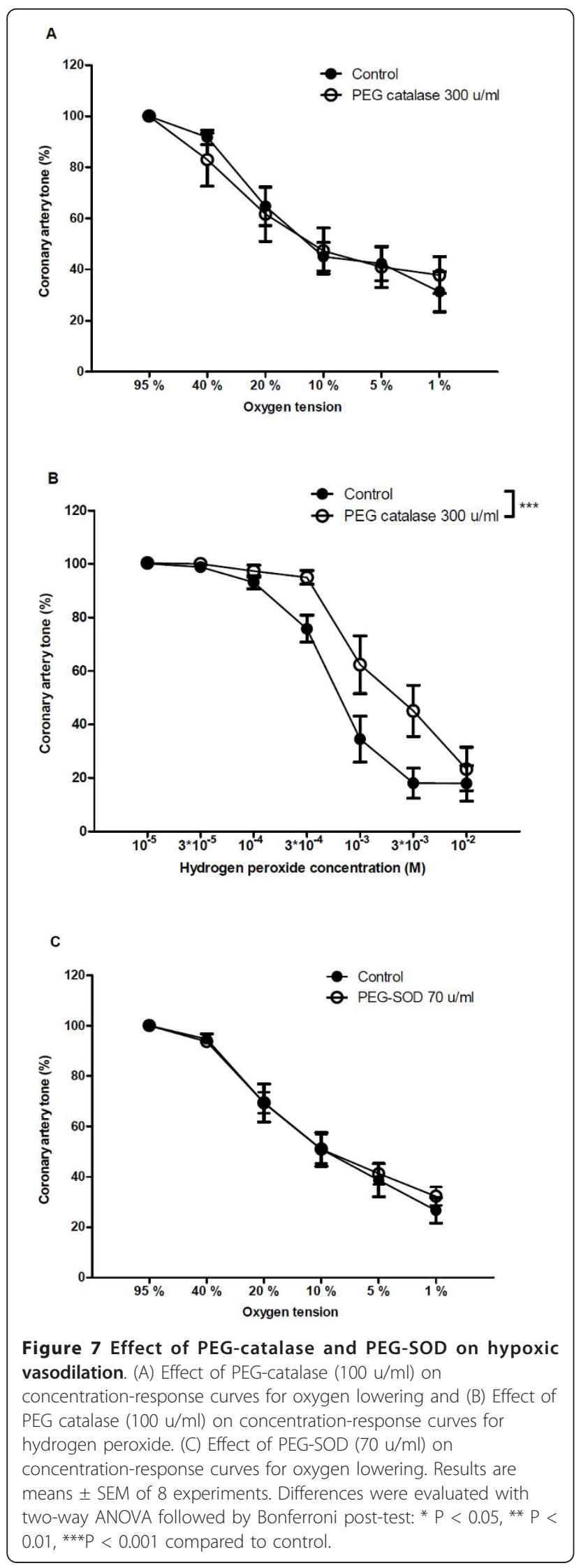

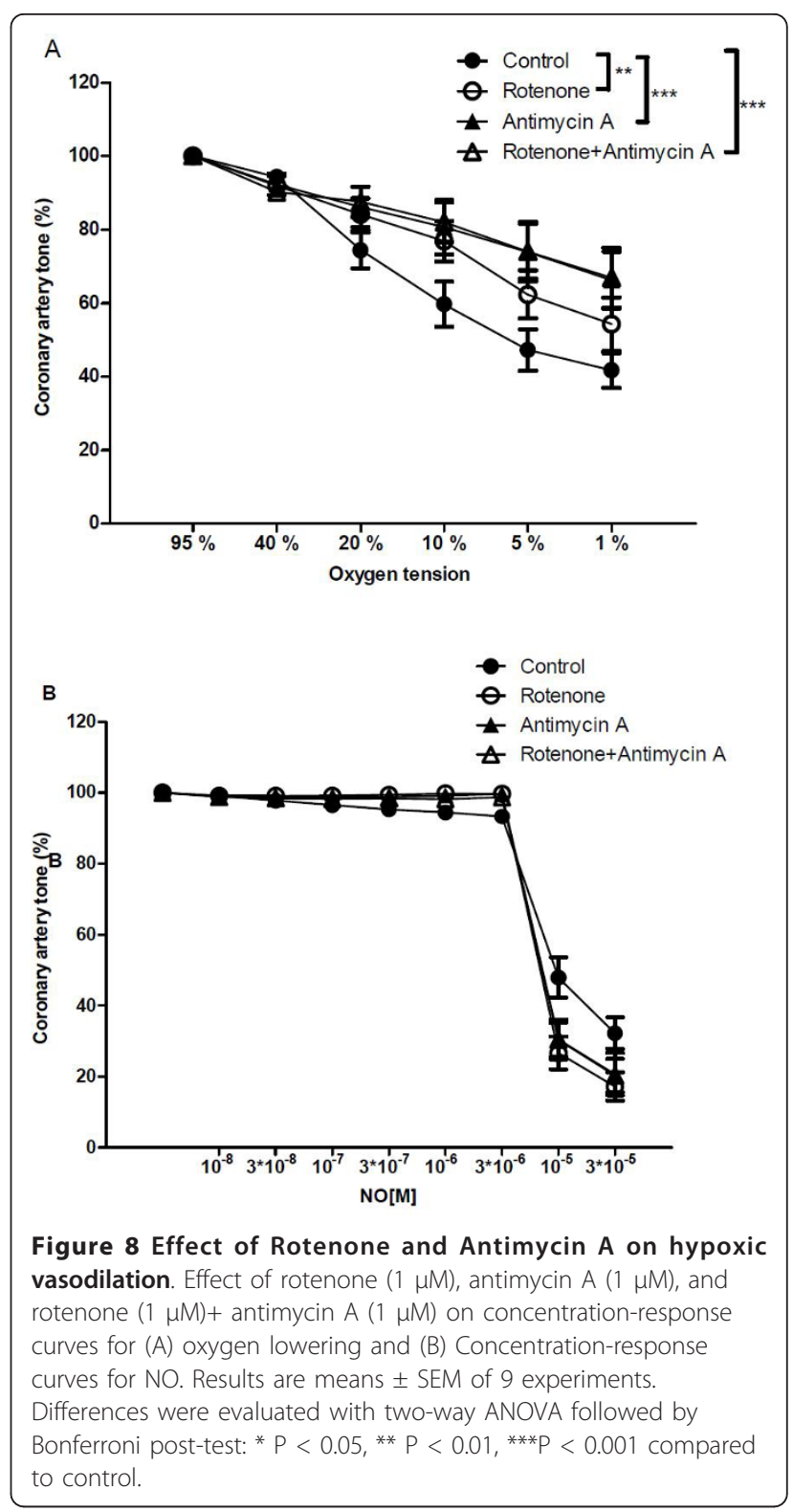

mitochondrial inhibitors did not change NO relaxation (Figure 8B).

\section{Discussion}

There are three major findings of the present in vitro investigation. First, endothelin receptor activation reverses while endothelin receptor antagonism markedly enhances hypoxic vasodilation in pig coronary arteries with and without endothelium. These findings suggest that endothelin counteracts hypoxic vasodilation in porcine coronary arteries independently of the endothelium. Second NO release was augmented during hypoxia and L-NOARG inhibited hypoxia-induced relaxation suggesting that NO contributes to hypoxic relaxation. Since a non-specific $\mathrm{K}$ channel blocker, TEA inhibited 
relaxations induced by $\mathrm{O}_{2}$ lowering or $\mathrm{NO}$, the counteracting effect of endothelin on hypoxic vasodilation may take place through inhibition of $\mathrm{K}$ channels. Third, there was no additional release of ADMA or indication of additional release of oxygen free radicals during severe hypoxia (5 and $1 \% \mathrm{O}_{2}$ ).

\section{Endothelin counteracts hypoxic vasodilation}

Despite overall vasodilation to hypoxia, previous studies report increased endothelial release of ET-1 in response to hypoxia in systemic arteries $[7,8]$, and hypoxia was suggested to increase ET-1 levels in cultured human umbilical venous endothelial cells exposed to 24 hours of hypoxia [26]. In addition to the endothelium, formation of endothelin can also take place in smooth muscle and adventitial cells of the vascular wall $[27,28]$. In the present study we were able to measure changes in endothelin concentration when it was added exogenously, but we did not observe any difference in the amount of ET-1 in porcine coronary arteries exposed to hypoxia. We cannot exclude the possibility that stoichiometric binding of endothelin may differ in normoxic versus hypoxic situations. Previous studies in rats show that most cardiac endothelin receptors are free of bound endothelin [29] and that ischemia-reperfusion increases ET-1 binding in rabbit hearts [30]. Such changes would not have been reflected in tissue endothelin concentrations as measured by our ELISA assay. However, the mixed endothelin receptor antagonist SB217242 (enrasentan) increased relaxation regardless of the presence or absence of endothelium. In previous studies we have found that endothelin contraction is antagonized by the $\mathrm{ET}_{\mathrm{A}}$ receptor antagonists BQ123 as well as by SB217242 [31] in the porcine coronary arteries [19].

Previous studies have suggested that exposure to hypoxic conditions may enhance the response to endothelin. Thus, in an in vitro study of pig coronary subendocardial arterioles two weeks after myocardial infarction an increased vasoconstrictor response to ET-1 was observed in vessels from animals with myocardial infarction compared to vessels from control animals [32], and an increased vasoconstriction to endothelin was found in the coronary arteries after ischemia-reperfusion of the porcine heart [33]. In the present study, addition of exogenous endothelin-1 reversed hypoxic vasodilation and endothelin contraction was enhanced in the arteries exposed to hypoxia. Together with enhanced vasorelaxation in the presence of an endothelin receptor antagonist, and the lack of change in vascular wall endothelin concentration, these findings suggest that endothelin counteracts hypoxic vasodilation probably due to an increased endothelin receptor activation of hypoxic arteries.
A non-endothelial origin of endothelin has previously been suggested based on the observation that the $\mathrm{ET}_{\mathrm{A}}$ antagonist BQ123 inhibited anoxic contractions in canine coronary arteries without endothelium [4]. In the present study, the non-endothelial origin of endothelin is supported by our observation that an endothelin receptor antagonist enhances relaxation to $\mathrm{O}_{2}$ lowering in arteries without endothelium and that contribution of endothelial-derived endothelin to the measured amount of endothelin in the porcine coronary arteries was insignificant (Figure 2).

\section{Role of NO in hypoxic vasodilatation}

Studies using both wire-based and pressurised in vitro set-ups have found that inhibition of NO synthesis reduces hypoxic vasodilation [34-37], although LNOARG had no effect on hypoxic relaxation in rat conduit coronary arteries [38]. Also, in vivo, Nase et al. [39] measured NO release in rat intestinal arterioles by means of microelectrodes and found a two-fold increase in arteriolar NO concentration during oxygen reduction. In the present study direct measurements of $\mathrm{NO}$ also suggest that NO increases in contracted arteries exposed to hypoxia. Together with the observation that the concentration-response curves for $\mathrm{O}_{2}$ lowering are rightward shifted by endothelial cell removal, and by an inhibitor of NO synthase, L-NOARG, these findings suggest that NO contributes to hypoxic vasodilation in porcine coronary arteries. However, experiments in arterial segments without endothelium or after inhibition of the NO-cGMP pathway in the present study, also revealed that smooth muscle vasodilatory pathways independent of the endothelial cell layer appear to contribute to hypoxic vasodilation in porcine large coronary arteries.

Following our recent findings that the plasma concentration of the endogenous NO synthase inhibitor, ADMA, rises in patients with myocardial infarction [13] and that ADMA reduces coronary artery contraction to hyperoxia [19] it was logical to investigate the role of ADMA in hypoxic coronary dilation. We were able to recover ADMA when it was added, but the concentration of ADMA was extremely low in coronary artery interstitial fluid and did not rise during hypoxia. Addition of pathophysiologically relevant concentrations $\left(10^{-}\right.$

${ }^{5} \mathrm{M}$, derived from our previous human study [13]) of ADMA to the organ bath did not change the arterial response to hypoxia. Moreover, these concentrations of ADMA only cause incomplete inhibition of eNOS [21]. Therefore these findings suggest that ADMA in the blood stream does not appear to play a role in hypoxiainduced diameter changes.

It is well accepted that NO derived from the endothelium or drugs promotes vascular relaxation through 
stimulation of soluble guanylate cyclase and generation of cyclic GMP [40]. Hypoxia has also been found to increase cyclic GMP formation in bovine pulmonary arteries [41]. However, in contrast to inhibition of NO synthase with L-NOARG, inhibition of soluble guanylate cyclase by ODQ failed to reduce relaxations induced by $\mathrm{O}_{2}$ lowering, although $\mathrm{NO}$ relaxations were reduced. These findings suggest that endothelium-derived NO in hypoxic conditions may cause guanylate cyclaseindependent relaxations.

The NO-cGMP pathway can lead to activation of smooth muscle ATP-sensitive and large-conductance calcium-activated $\mathrm{K}\left(\mathrm{BK}_{\mathrm{Ca}}\right)$ channels both through protein kinase $\mathrm{G}$ dependent and independent pathways $[42,43]$. In the present study, the non-specific K channel blocker TEA inhibited relaxations induced by $\mathrm{O}_{2}$ lowering both in the absence and the presence of ODQ, and also inhibited relaxations induced by exogenously added NO. ODQ was reported to cause less inhibition of the NO donor, S-nitroso-N-acetylpencillamin-induced relaxation in bovine pulmonary arteries exposed to hypoxia [41], and together with our finding that activation of TEA-sensitive channels is involved both in the hypoxic and NO-induced relaxations in porcine coronary arteries, these findings may suggest that $\mathrm{K}$ channels are involved in the relaxations induced by the increased NO observed in acute hypoxia, although other mechanism such as NO-mediated inhibition of smooth muscle sarcoplasmic Ca-ATPase may also contribute [41]. Endothelin has also been shown to inhibit $\mathrm{K}_{\mathrm{ATP}}$ channel conductance [44], and BK channels [45] in porcine coronary artery smooth muscle cells. This latter effect of endothelin may explain how hypoxic relaxation is counteracted in porcine large coronary arteries.

\section{Role of ROS and mitochondrial enzymes in hypoxic vasodilation}

ROS are natural by-products of the normal metabolism of oxygen and are essential in cell signalling. ROS include superoxide anion $\left(\mathrm{O}_{2}{ }^{-}\right)$, the electronically excited singlet oxygen $\left({ }^{1} \mathrm{O}_{2}\right)$, hydrogen peroxide $\left(\mathrm{H}_{2} \mathrm{O}_{2}\right)$, and hydroxyl radical $(\mathrm{OH})$. Saitoh et al. [46] suggested that $\mathrm{H}_{2} \mathrm{O}_{2}$ is produced in a feed forward fashion in proportion to cardiac metabolism and is directly coupled to coronary blood flow [46]. Some studies support such a feed forward theory $[47,48]$ while results from other studies oppose it $[49,50]$. In this study ROS inhibition with apocynin or tiron inhibited vasorelaxation to moderate $\mathrm{O}_{2}$ levels $\left(10 \% \mathrm{O}_{2}\right)$, but failed to alter porcine coronary dilation in severe hypoxic conditions $\left(1 \% \mathrm{O}_{2}\right)$. Moreover, the effect of tiron and apocynin was only present in segments with endothelium suggesting that in moderate hypoxic conditions ROS formation may counteract hypoxic vasodilation by reacting with endothelium- derived NO. Superoxide dismutase and catalase scavenge, respectively, extracellular $\mathrm{O}_{2}{ }^{-}$and $\mathrm{H}_{2} \mathrm{O}_{2}$ and in the pegylated forms, the penetration into the vascular wall is increased of these molecules. However, PEGSOD and PEG-catalase failed to change relaxations induced by $\mathrm{O}_{2}$ lowering, although PEG-catalase inhibited exogenously added $\mathrm{H}_{2} \mathrm{O}_{2}$. These results agree with recent findings in fetal chicken femoral arteries where PEG-SOD and PEG-catalase also failed to change relaxation in severe hypoxia [51]. Although we cannot exclude non-specific effects of tiron and apocynin [52,53], the effects of both tiron and apocynin appear to be specific, since the effects of moderate $\mathrm{O}_{2}$ levels are only observed in segments with endothelium. Therefore, a likely explanation for these results is that the reaction of $\mathrm{NO}$ and $\mathrm{O}_{2}{ }^{-}$to form $\mathrm{ONOO}^{-}$is too fast to allow the reaction of $\mathrm{O}_{2}{ }^{-}$with the antioxidant e.g. PEG-SOD in the vascular wall [54]. However, overall the results of the present study suggest that ROS do not appear to play a major role in relaxations associated with severe hypoxia.

The mitochondrial electron transport chain is in hypoxic conditions both considered as $\mathrm{O}_{2}$ sensor and a source of NO accumulation due to decreased metabolization of $\mathrm{NO}$ by cytochrome $\mathrm{C}$ in a reduced state $[55,56]$. Hypoxia-induced relaxations have previously been reported to be reduced by inhibitors of the mitochondrial electron transport chain complex I (rotenone), complex III (myxothiazole and antimycin A), and complex IV $\left(\mathrm{NaN}_{3}\right)$ [51,57]. In the present study both rotenone and antimycin A reduced relaxation induced by $\mathrm{O}_{2}$ lowering. Rotenone and antimycin A were also found to increase formation of $\mathrm{O}_{2}{ }^{-}$in bovine coronary arteries [57]. However, in the present study rotenone and antimycin A did not change relaxations induced by exogenously added NO, and hence NO bioavailability. Therefore, our results do not suggest a role for ROS in severe hypoxia in porcine coronary arteries. Thus, our results agree with observations in bovine coronary arteries that ROS are not primary mediators of the hypoxic relaxation, but sustain the presence of an $\mathrm{O}_{2}$ sensing/signaling model based on mitochondrial control of pyruvate metabolism associated with cytosolic NADPH redox regulation [55,57]. In addition to the mitochondrial $\mathrm{O}_{2}$ sensing/signaling in smooth muscle relaxation, our findings of increased $\mathrm{NO}$ formation in hypoxic conditions (Figure 4), support an endothelial mitochondrial sensing mechanism leading to increased NO formation.

\section{Conclusions}

The present results in porcine coronary arteries suggest NO contributes to hypoxic vasodilation, probably through the $\mathrm{K}$ channels, which is reversed by addition of ET-1 and enhanced by endothelin receptor 
antagonism. These latter findings suggest that endothelin receptor activation counteracts hypoxic vasodilation.

The dilatory response to hypoxia is important in the resistance arteries of the coronary circulation, but the dilatory response to hypoxia is also present in conduit vessels $[1,58,59]$. Combined with the fact that coronary atherosclerosis is confined to epicardial arteries, even minor diameter changes become highly important when a hemodynamically significant stenosis is present. In quantitative terms other scientific groups as well as ourselves typically find a $20 \%$ increase in conductance coronary artery diameter during hypoxia (the pressure myograph findings in this study). According to Poiseuille's law this equals a doubling in flow rate. In heart disease hypoxia is also a prominent feature of heart failure, but while local hypoxia may alter cellular function in the myocardium, systemic hypoxia may improve ventricular function secondary to changes in vascular tone [60]. In the atherosclerotic human coronary circulation endothelium-dependent vasodilation is impaired [61] and this is associated with an increased frequency of cardiac events. Release of endothelium-derived NO is decreased in endothelial dysfunction and could thus not contribute to hypoxic vasodilation and counteract the contractile effect of ET-1. Based on the present preclinical findings it would be interesting to investigate the therapeutic potential of endothelin receptor antagonists in ischemic heart disease although unexpected hemodynamic changes have been reported previously [62].

\footnotetext{
Acknowledgements

The study was supported by The Danish Heart Foundation and the Danish Medical Research Council. We thank Margit Nielsen for excellent assistance in myograph studies and Karen K. Busch for expert analysis of ADMA.
}

\section{Author details}

${ }^{1}$ Department of Pharmacology, Aarhus University, Wilhem Meyers Allé 4, Bldg. 1240, 8000 Aarhus C, Denmark. ²Department of Physiology, Medical Academy, Lithuanian University of Health Sciences, A. Mickevičiaus 9, 44307 Kaunas, Lithuania. ${ }^{3}$ Department of Cardiology, Örebro University Hospital, Södra Grev Rosengatan, 70185 Örebro, Sweden.

\section{Authors' contributions}

ERH carried out the ET-1 measurements and myography studies, and performed statistical analysis and participated in study design and writing of the manuscript. ES carried out the NO measurements and performed some of the statistical analysis. US and OF participated in the design and idea of the study as well as in the writing of the manuscript. All authors have read and approved the final manuscript.

Received: 10 November 2010 Accepted: 15 May 2011

Published: 15 May 2011

\section{References}

1. Wadsworth RM: Vasoconstrictor and vasodilator effects of hypoxia. Trends Pharmacol Sci 1994, 15:47-53.

2. Tune JD: Control of coronary blood flow during hypoxemia. Adv Exp Med Biol 2007, 618:25-39.

3. Graser T, Vanhoutte PM: Hypoxic contraction of canine coronary arteries: role of endothelium and cGMP. Am J Physiol 1991, 261:H1769-H1777.
4. Vedernikov YP, Goto K, Vanhoutte PM: The ETA antagonist BQ-123 inhibits anoxic contractions of canine coronary arteries without endothelium. J Cardiovasc Pharmacol 1993, 22(Suppl 8):S252-S256.

5. Kwan YW, Kane KA: Modification of the ischaemic-induced contraction in the sheep circumflex coronary artery by various pharmacological antagonists. Br J Pharmacol 1990, 100:407-412.

6. Rubanyi GM, Paul RJ: Two distinct effects of oxygen on vascular tone in isolated porcine coronary arteries. Circ Res 1985, 56:1-10.

7. Rakugi H, Tabuchi Y, Nakamaru M, Nagano M, Higashimori K, Mikami H, Ogihara T, Suzuki N: Evidence for endothelin-1 release from resistance vessels of rats in response to hypoxia. Biochem Biophys Res Commun 1990, 169:973-977.

8. Hieda HS, Gomez-Sanchez CE: Hypoxia increases endothelin release in bovine endothelial cells in culture, but epinephrine, norepinephrine, serotonin, histamine and angiotensin II do not. Life Sci 1990, 47:247-251.

9. Dhaun N, Pollock DM, Goddard J, Webb DJ: Selective and mixed endothelin receptor antagonism in cardiovascular disease. Trends Pharmacol Sci 2007, 28:573-579.

10. Duerrschmidt N, Wippich N, Goettsch W, Broemme HJ, Morawietz H: Endothelin-1 induces $\mathrm{NAD}(\mathrm{P}) \mathrm{H}$ oxidase in human endothelial cells. Biochem Biophys Res Commun 2000, 269:713-717.

11. Beppu M, Obayashi S, Aso T, Goto M, Azuma H: Endogenous nitric oxide synthase inhibitors in endothelial cells, endothelin-1 within the vessel wall, and intimal hyperplasia in perimenopausal human uterine arteries. J Cardiovasc Pharmacol 2002, 39:192-200.

12. Ohnishi M, Wada A, Tsutamoto T, Fujii M, Matsumoto T, Yamamoto T, Takayama T, Wang X, Kinoshita M: Endothelin stimulates an endogenous nitric oxide synthase inhibitor, asymmetric dimethylarginine, in experimental heart failure. Clin Sci (Lond) 2002, 103(Suppl 48):241S-244S.

13. Frøbert $\mathrm{O}$, Hjortshoj SP, Simonsen U, Ravkilde J: Methylated arginines in stable and acute patients with coronary artery disease before and after percutaneous revascularization. Int J Cardiol 2007, 129:288-291.

14. Elmarakby AA, Morsing P, Pollock DM: Enalapril attenuates endothelin-1induced hypertension via increased kinin survival. Am J Physiol Heart Circ Physiol 2003, 284:H1899-H1903.

15. Simonsen U, Christensen FH, Buus NH: The effect of tempol on endothelium-dependent vasodilatation and blood pressure. Pharmacol Ther 2009, 122:109-124.

16. Beckman JS, Koppenol WH: Nitric oxide, superoxide, and peroxynitrite: the good, the bad, and ugly. Am J Physiol 1996, 271:C1424-C1437.

17. Bjornheden T, Evaldsson M, Wiklund O: A method for the assessment of hypoxia in the arterial wall, with potential application in vivo. Arterioscler Thromb Vasc Biol 1996, 16:178-185.

18. European Convention for the Protection of Vertebrate Animals used for Experimental and Other Scientific Purposes. 2010 [http://conventions.coe. int/Treaty/en/Treaties/html/123.htm], Ref Type: Online Source.

19. Pasgaard T, Stankevicius E, Jorgensen MM, Ostergaard L, Simonsen U, Frøbert $O$ : Hyperoxia reduces basal release of nitric oxide and contracts porcine coronary arteries. Acta Physiol (Oxf) 2007, 191:285-296.

20. Mulvany MJ, Warshaw DM: The active tension-length curve of vascular smooth muscle related to its cellular components. J Gen Physiol 1979, 74:85-104

21. Stankevicius E, Martinez AC, Mulvany MJ, Simonsen U: Blunted acetylcholine relaxation and nitric oxide release in arteries from rena hypertensive rats. J Hypertens 2002, 20:1571-1579.

22. Frøbert $\mathrm{O}$, Mikkelsen EO, Bagger JP: The influence of transmural pressure and longitudinal stretch on $\mathrm{K}+-$ and $\mathrm{Ca} 2+-$ induced coronary artery constriction. Acta Physiol Scand 1999, 165:379-385.

23. Frøbert O, Mikkelsen EO, Bagger JP, Gravholt CH: Measurement of interstitial lactate during hypoxia-induced dilatation in isolated pressurised porcine coronary arteries. J Physiol 2002, 539:277-284.

24. Boger RH, Bode-Boger SM, Szuba A, Tsao PS, Chan JR, Tangphao O, Blaschke TF, Cooke JP: Asymmetric dimethylarginine (ADMA): a novel risk factor for endothelial dysfunction: its role in hypercholesterolemia. Circulation 1998, 98:1842-1847.

25. Martinez AC, Stankevicius E, Jakobsen $P$, Simonsen U: Blunted non-nitric oxide vasodilatory neurotransmission in penile arteries from renal hypertensive rats. Vascul Pharmacol 2006, 44:354-362.

26. Gertler JP, Ocasio VH: Endothelin production by hypoxic human endothelium. J Vasc Surg 1993, 18:178-182. 
27. Hanehira T, Kohno M, Yoshikawa J: Endothelin production in cultured vascular smooth muscle cells-modulation by the atrial, brain, and Ctype natriuretic peptide system. Metabolism 1997, 46:487-493.

28. Davie NJ, Gerasimovskaya EV, Hofmeister SE, Richman AP, Jones PL, Reeves JT, Stenmark KR: Pulmonary artery adventitial fibroblasts cooperate with vasa vasorum endothelial cells to regulate vasa vasorum neovascularization: a process mediated by hypoxia and endothelin-1. Am J Pathol 2006, 168:1793-1807.

29. Ferrari E, Talbodec A, Vigne P, Frelin C: Evidence for receptor bound endothelin in renal but not in cardiac tissues from normal rats. Cardiovasc Res 1998, 38:140-148.

30. Saito T, Fushimi E, Tamura T, Fujiwara Y, Miura H, Watanabe H, Kibira S, Hasegawa H, Miura M: L-nitro-arginine inhibits increase in endothelin binding sites induced by ischemia and reperfusion. J Mol Cell Cardiol 2002, 34:1041-1047.

31. Ohlstein EH, Nambi $P$, Lago A, Hay DW, Beck G, Fong KL, Eddy EP, Smith P, Ellens $\mathrm{H}$, Elliott JD: Nonpeptide endothelin receptor antagonists. VI: Pharmacological characterization of SB 217242, a potent and highly bioavailable endothelin receptor antagonist. J Pharmacol Exp Ther 1996, 276:609-615.

32. Merkus D, Houweling B, van Den Meiracker AH, Boomsma F, Duncker DJ: Contribution of endothelin to coronary vasomotor tone is abolished after myocardial infarction. Am J Physiol Heart Circ Physiol 2005, 288 H871-H880.

33. Climent B, Fernandez N, Sanz E, Sanchez A, Monge L, Garcia-Villalon AL, Dieguez G: Enhanced response of pig coronary arteries to endothelin-1 after ischemia-reperfusion. Role of endothelin receptors, nitric oxide and prostanoids. Eur J Pharmacol 2005, 524:102-110.

34. Jimenez AH, Tanner MA, Caldwell WM, Myers PR: Effects of oxygen tension on flow-induced vasodilation in porcine coronary resistance arterioles. Microvasc Res 1996, 51:365-377.

35. Edmunds NJ, Moncada S, Marshall JM: Does nitric oxide allow endothelial cells to sense hypoxia and mediate hypoxic vasodilatation? In vivo and in vitro studies. J Physiol 2003, 546:521-527.

36. Jiang C, Collins P: Inhibition of hypoxia-induced relaxation of rabbit isolated coronary arteries by NG-monomethyl-L-arginine but not glibenclamide. Br J Pharmacol 1994, 111:711-716.

37. Brown IP, Thompson Cl, Belloni FL: Role of nitric oxide in hypoxic coronary vasodilatation in isolated perfused guinea pig heart. Am J Physiol 1993, 264:H821-H829.

38. Kerkhof CJ, Van Der Linden PJ, Sipkema P: Role of myocardium and endothelium in coronary vascular smooth muscle responses to hypoxia. Am J Physiol Heart Circ Physiol 2002, 282:H1296-H1303.

39. Nase GP, Tuttle J, Bohlen HG: Reduced perivascular PO2 increases nitric oxide release from endothelial cells. Am J Physiol Heart Circ Physiol 2003, 285: $\mathrm{H} 507-\mathrm{H} 515$.

40. Archer SL, Huang JM, Hampl V, Nelson DP, Shultz PJ, Weir EK: Nitric oxide and CGMP cause vasorelaxation by activation of a charybdotoxinsensitive K channel by cGMP-dependent protein kinase. Proc Natl Acad Sci USA 1994, 91:7583-7587.

41. Mingone CJ, Gupte SA, lesaki T, Wolin MS: Hypoxia enhances a CGMPindependent nitric oxide relaxing mechanism in pulmonary arteries. Am J Physiol Lung Cell Mol Physiol 2003, 285:L296-L304.

42. Vanhoutte PM: Say NO to ET. J Auton Nerv Syst 2000, 81:271-277.

43. Boulanger C, Luscher TF: Release of endothelin from the porcine aorta. Inhibition by endothelium-derived nitric oxide. J Clin Invest 1990, 85:587-590.

44. Miyoshi Y, Nakaya Y, Wakatsuki T, Nakaya S, Fujino K, Saito K, Inoue I: Endothelin blocks ATP-sensitive K+ channels and depolarizes smooth muscle cells of porcine coronary artery. Circ Res 1992, 70:612-616.

45. Hu SL, Kim HS, Jeng AY: Dual action of endothelin-1 on the Ca2 (+)-activated $\mathrm{K}+$ channel in smooth muscle cells of porcine coronary artery. Eur J Pharmacol 1991, 194:31-36.

46. Saitoh S, Zhang C, Tune JD, Potter B, Kiyooka T, Rogers PA, Knudson JD, Dick GM, Swafford A, Chilian WM: Hydrogen peroxide: a feed-forward dilator that couples myocardial metabolism to coronary blood flow. Arterioscler Thromb Vasc Biol 2006, 26:2614-2621.

47. Bhat GB, Tinsley SB, Tolson JK, Patel JM, Block ER: Hypoxia increases the susceptibility of pulmonary artery endothelial cells to hydrogen peroxide injury. J Cell Physiol 1992, 151:228-238.
48. Kaminski PM, Wolin MS: Hypoxia increases superoxide anion production from bovine coronary microvessels, but not cardiac myocytes, via increased xanthine oxidase. Microcirculation 1994, 1:231-236.

49. Pohl U, Busse R: Hypoxia stimulates release of endothelium-derived relaxant factor. Am J Physiol 1989, 256:H1595-H1600.

50. Thomson AJ, Drummond GB, Waring WS, Webb DJ, Maxwell SR: Effects of short-term isocapnic hyperoxia and hypoxia on cardiovascular function J Appl Physiol 2006, 101:809-816.

51. Zoer B, Cogolludo AL, Perez-Vizcaino F, De Mey JG, Blanco CE, Villamor E: Hypoxia sensing in the fetal chicken femoral artery is mediated by the mitochondrial electron transport chain. Am J Physiol Regul Integr Comp Physiol 2010, 298:R1026-R1034.

52. Heumuller S, Wind S, Barbosa-Sicard E, Schmidt HH, Busse R, Schroder K, Brandes RP: Apocynin is not an inhibitor of vascular NADPH oxidases but an antioxidant. Hypertension 2008, 51:211-217.

53. Han WQ, Wong WT, Tian XY, Huang Y, Wu LY, Zhu DL, Gao PJ: Contributory role of endothelium and voltage-gated potassium channels in apocynin-induced vasorelaxations. J Hypertens 2010, 28:2102-2110.

54. Simonsen U, Rodriguez-Rodriguez R, Dalsgaard T, Buus NH, Stankevicius E: Novel approaches to improving endothelium-dependent nitric oxidemediated vasodilatation. Pharmacol Rep 2009, 61:105-115.

55. Wolin MS: Reactive oxygen species and the control of vascular function Am J Physiol Heart Circ Physiol 2009, 296:H539-H549.

56. Taylor CT, Moncada S: Nitric oxide, cytochrome $C$ oxidase, and the cellular response to hypoxia. Arterioscler Thromb Vasc Biol 2010, 30:643-647.

57. Gao Q, Zhao X, Ahmad M, Wolin MS: Mitochondrial-derived hydrogen peroxide inhibits relaxation of bovine coronary arterial smooth muscle to hypoxia through stimulation of ERK MAP kinase. Am J Physiol Heart Circ Physiol 2009, 297:H2262-H2269.

58. Barron JT, Gu L: Energetic effects of adenosine on vascular smooth muscle. Am J Physiol Heart Circ Physiol 2000, 278:H26-H32.

59. Shimizu S, Bowman PS, Thorne G, Paul RJ: Effects of hypoxia on isometric force, intracellular $\mathrm{Ca}(2+), \mathrm{pH}$, and energetics in porcine coronary artery. Circ Res 2000, 86:862-870

60. Frøbert O, Moesgaard J, Toft E, Poulsen SH, Sogaard P: Influence of oxygen tension on myocardial performance. Evaluation by tissue Doppler imaging. Cardiovasc Ultrasound 2004, 2:22-30.

61. Ludmer PL, Selwyn AP, Shook TL, Wayne RR, Mudge GH, Alexander RW, Ganz P: Paradoxical vasoconstriction induced by acetylcholine in atherosclerotic coronary arteries. N Engl J Med 1986, 315:1046-1051.

62. Kyriakides ZS, Kremastinos DT, Kolokathis F, Kostopoulou A, Georgiadis M, Webb DJ: Acute endothelin(A) receptor antagonism improves coronary artery compliance in coronary artery disease patients. Clin Sci (Lond) 2002, 103(Suppl 48):179S-183S.

doi:10.1186/1472-6793-11-8

Cite this article as: Hedegaard et al:: Non-endothelial endothelin

counteracts hypoxic vasodilation in porcine large coronary arteries. BMC Physiology 2011 11:8.

\section{Submit your next manuscript to BioMed Central and take full advantage of:}

- Convenient online submission

- Thorough peer review

- No space constraints or color figure charges

- Immediate publication on acceptance

- Inclusion in PubMed, CAS, Scopus and Google Scholar

- Research which is freely available for redistribution

Submit your manuscript at www.biomedcentral.com/submit
C Biomed Central 